\title{
Role of IDEAL technique in diagnosing a rare parotid gland lipoma
}

\author{
Vikash Sharma, ${ }^{1}$ Rajaram Sharma 다 , 1,2 Tapendra Tiwari, ${ }^{1}$ Saurabh Goyal ${ }^{1}$
}

${ }^{1}$ Radio-diagnosis, Pacific Institute of Medical Sciences Umarda Campus, Udaipur, India ${ }^{2}$ Radio-diagnosis, Seth GS Medical College and KEM Hospital, Mumbai, India

\section{Correspondence to Dr Rajaram Sharma; hemantgalaria13@gmail.com}

Accepted 11 January 2022 (c) BMJ Publishing Group Limited 2022. No commercial re-use. See rights and permissions. Published by BMJ.

To cite: Sharma V, Sharma R, Tiwari T, et al. BMJ Case Rep 2022;15:e247382. doi:10.1136/bcr-2021247382

\section{DESCRIPTION}

Lipoma is the most commonly found benign tumour in any location that contains fat, but its occurrence is relatively rare in the head and neck region; when present, it mainly involves the posterior part of the neck. Parotid lipoma comprises only $0.6 \%-4.4 \%$ of the reported benign parotid neoplasms. ${ }^{1}$ It is a slowgrowing tumour that remains asymptomatic until it reaches a larger size and gradually compresses the surrounding structures. The superficial lobe is a commonly involved lobe in the parotid gland, and only a few cases of deep lobe parotid lipomas have been reported in the literature. However, lipoma in the salivary gland is rare ${ }^{23}$ and is often mistaken for a Warthin tumour or pleomorphic adenoma. It is surgically removed if the swelling increases significantly or there is any functional/cosmetic discomfort to the patient. ${ }^{4}$ Therefore, accurate localisation and anatomical relations are essential in presurgical planning, considering its proximity to facial nerves and other structures.

Preoperative radiation-free imaging studies that can differentiate a parotid soft tissue mass include ultrasonography (US) and MRI. On the US, it appears as a round-shaped to oval-shaped, welldefined, hyperechoic mass. ${ }^{5}$ However, deep lobe lipomas are not commonly seen on the US. MRI is

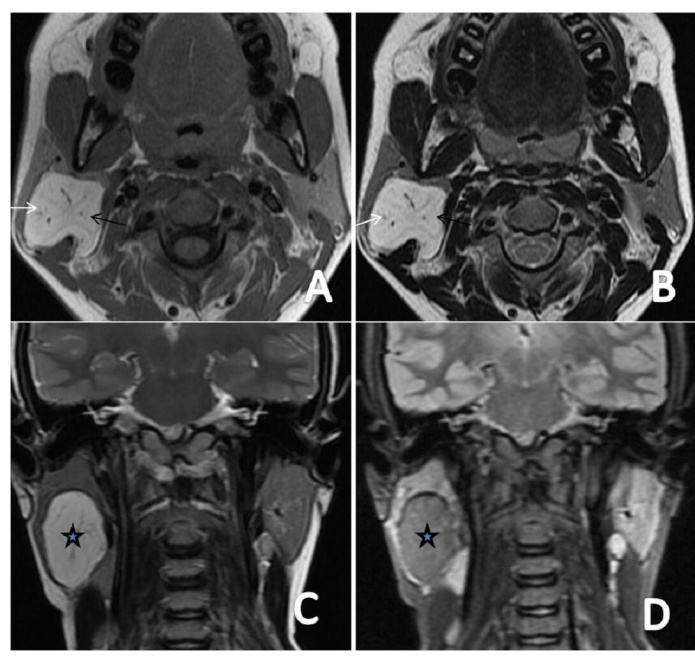

Figure 1 MRIs of parotid lipoma. (A) T1-weighted axial plane and (B) T2-weighted axial plane images depicting a well-defined hyperintense lesion in right parotid gland (white arrow) signifying the fat nature of the lesion. Also note the small extension of the lesion into the deep lobe of parotid gland (black arrow). T2-weighted coronal plane image (C) demonstrates a well-defined hyperintense lobulated lesion (asterisk) in right parotid gland which suppresses on short tau inversion recovery image (D).

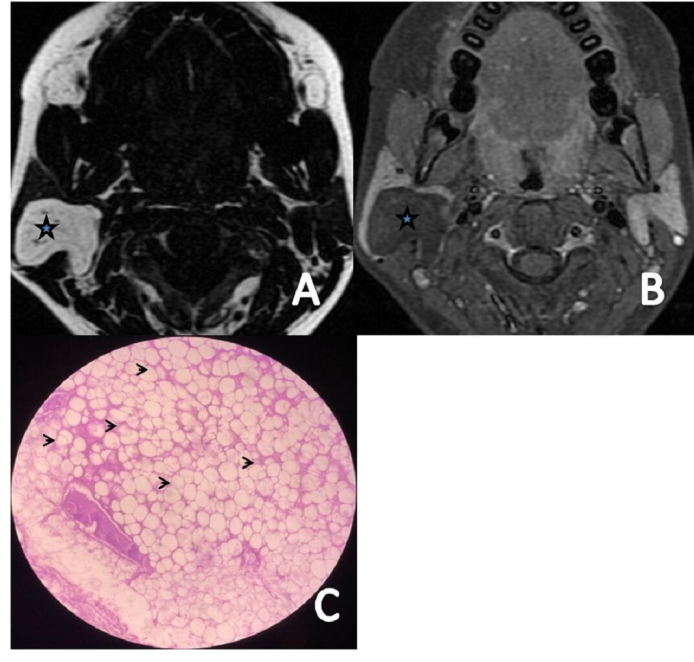

Figure 2 MRIs. (A) Fat-only IDEAL sequence in axial plane shows hyperintense signal of fat in the right parotid lesion (asterisk). (B) Water-only IDEAL sequence shows hypointense signal (asterisk) in the right parotid lesion. (C) Histopathological image at $10 \times$ shows sheets of adipocytes (black arrow).

the preferred imaging technique for the deep lobe pathologies that helps visualise the tumour capsule, its extension and its relation to surrounding tissues. MRI is also preferred for suspicious malignant lesions and to assess the relations with the facial nerve. $^{6}$

Lipomas present as a high signal on T1-weighted images (WI) as well as on T2WI. A definite diagnosis is made using 'iterative decomposition of water and fat with echo asymmetry and least-squares estimation' (IDEAL) technology that reconstructs fat-only and water-only images. The IDEAL technique uses chemical transport or resonant frequency changes to decompose fat proton and water proton signals, and it forms two different images of these two components separately.

The use of the Dixon method (IDEAL sequence) is impeccable for such type of lesions as it separates water and fat protons and forms images separately instead of suppressing the fat. ${ }^{78}$ Benign and malignant pleomorphic adenomas and mucoepidermoid carcinoma tumours are variably T2 hyperintense and are enhanced differently. The Warthin tumour is T2 hypointense, and oncocytoma is T1 hypointense.

A 38-year-old male patient presented to our hospital with a painless progressive right-sided cheek swelling. Clinical examination revealed a firm consistency, non-tender, non-pulsatile and 
non-fluctuant intraglandular mass in the right parotid gland. His facial nerve functions were intact. No palpable cervical lymph nodes were detected. The patient also had a US report suggesting an ill-defined mass probably arising from the deep lobe of the parotid gland. The patient underwent an MRI scan of the neck, which revealed a lesion that appeared hyperintense on T1WI (figure 1A) and T2WI (figure 1B,C), and hypointense on short tau inversion recovery (figure $1 \mathrm{D})$. The lesion appeared hyperintense on fat-only IDEAL images (figure 2A) and hypointense on water-only IDEAL images (figure 2B). Contrast-enhanced MRI did not reveal any enhancement in the lesion. The lesion was smoothly marginated with well-distinct borders and without any invasion of the surrounding structures. It measured $27 \times 28 \times 45$ $\mathrm{mm}$ in its maximum dimensions. The lesion was diagnosed as lipoma involving deep as well as superficial lobes of the parotid gland. Even after the counselling about the benign nature of

\section{Patient's perspective}

I was found to have a swelling on the right side of my neck two months back. I thought it would subside by itself but kept increasing in size. Then I came to the hospital, where I diagnosed benign fatty tumour. I had the surgery, and now I am feeling ok.

\section{Learning points}

- IDEAL technique imaging offers uniform and reliable fat suppression across the body, making it valuable for fatcontaining lesions.

- MRI is the ideal modality to assess parotid lesions as it provides superior soft tissue contrast resolution and better differentiation between the soft tissue lesions. the lesion to the patient, the patient opted for a surgery. Postoperatively, the excised lesion was sent for histopathological examinations. Histopathological slides demonstrated multiple fat-containing adipose cells (figure $2 \mathrm{C}$ ). The facial nerve functions are intact in the postoperative period, and the patient is on regular follow-up.

Contributors VS and RS contributed to the planning, conduct, reporting, conception and design, acquisition of data, or analysis and interpretation of data. TT and SG contributed to the acquisition of data and interpretation of data.

Funding The authors have not declared a specific grant for this research from any funding agency in the public, commercial or not-for-profit sectors.

Competing interests None declared.

Patient consent for publication Obtained.

Provenance and peer review Not commissioned; externally peer reviewed.

Case reports provide a valuable learning resource for the scientific community and can indicate areas of interest for future research. They should not be used in isolation to guide treatment choices or public health policy.

\section{ORCID iD}

Rajaram Sharma http://orcid.org/0000-0003-1126-5875

\section{REFERENCES}

1 Tong KN, Seltzer S, Castle JT. Lipoma of the parotid gland. Head Neck Pathol 2020;14:220-3.

2 El-Monem MHA, Gaafar AH, Magdy EA. Lipomas of the head and neck: presentation variability and diagnostic work-up. J Laryngol Otol 2006;120:47-55.

3 Korentager R, Noyek AM, Chapnik JS, et al. Lipoma and liposarcoma of the parotid gland: high-resolution preoperative imaging diagnosis. Laryngoscope 1988;98:967-71.

4 Fakhry N, Michel J, Varoquaux A, et al. Is surgical excision of lipomas arising from the parotid gland systematically required? Eur Arch Otorhinolaryngol 2012:269:1839-44.

5 Husain N, Bandhauer F, Kurrer M, et al. Lipoma of the parotid gland. Neuroradiol J 2008:21:81-6.

6 Paparo F, Massarelli M, Giuliani G. A rare case of parotid gland lipoma arising from the deep lobe of the parotid gland. Ann Maxillofac Surg 2016;6:308-10.

7 Starkman SJ, Olsen SM, Lewis JE, et al. Lipomatous lesions of the parotid gland: analysis of 70 cases. Laryngoscope 2013;123:651-6.

8 Costa DN, Pedrosa I, McKenzie C, et al. Body MRI using ideal. AJR Am J Roentgenol 2008; 190:1076-84.

Copyright 2022 BMJ Publishing Group. All rights reserved. For permission to reuse any of this content visit

https://www.bmj.com/company/products-services/rights-and-licensing/permissions/

BMJ Case Report Fellows may re-use this article for personal use and teaching without any further permission.

Become a Fellow of BMJ Case Reports today and you can:

- Submit as many cases as you like

- Enjoy fast sympathetic peer review and rapid publication of accepted articles

- Access all the published articles

Re-use any of the published material for personal use and teaching without further permission

Customer Service

If you have any further queries about your subscription, please contact our customer services team on +44 (0) 2071111105 or via email at support@bmj.com.

Visit casereports.bmj.com for more articles like this and to become a Fellow 